(1)

George Fox

UNIVERSITY
Digital Commons @ George Fox University

Promoting Educational Opportunity and Achievement Through 1:1 iPads

Gayle Y. Thieman

Tatiana Cevallos

Follow this and additional works at: https://digitalcommons.georgefox.edu/soe_faculty

Part of the Education Commons 


\title{
Promoting educational opportunity and achievement through 1:1 iPads
}

\author{
Gayle Y. Thieman \\ Graduate School of Education, Portland State University, Portland, \\ Oregon, USA, and \\ Tatiana Cevallos \\ Portland Tigard Center, George Fox University, Portland, Oregon, USA
}

\begin{abstract}
Purpose - The purpose of this paper is to expand the growing body of research on the educational impact of 1:1 mobile devices, investigating the iPad's potential to reduce the disparity of access to high-quality instructional technology and achievement for low income, racially, and linguistically diverse students.

Design/methodology/approach - This three-year, mixed-method study investigated the degree to which a 1:1 iPad initiative reduced the disparity of technology access and instructional use and improved student learning and attendance. The research design included survey data on student technology skills, experiences and use and teacher focus groups to confirm and contextualize the survey data.

Findings - Across all three years, ninth graders and students who were white, female, eligible for free/reduced lunch and those with stable enrollment were more likely to have an individual iPad (THP). Having a THP was associated with greater satisfaction, ease and frequency of technology use, higher attendance and GPA.

Research limitations/implications - Inequitable distribution, inconsistent administrative support, and uneven faculty support for iPads limit generalizability.

Practical implications - This research identifies barriers to successful technology integration and impact on student achievement including inequitable access, inconsistent administrative and teacher support, and limited professional development.

Originality/value - This research focuses on an issue of digital equity that has not yet been studied in depth with 1:1 iPads and investigates students' technology access, experiences and use to support student achievement in a high poverty, highly diverse high school.
\end{abstract}

Keywords iPad, Mobile learning, Digital equity, Research article

Paper type Research paper

The digital divide between technology mediated instructions for students in low vs high socio-economic schools is a serious equity issue with repercussions for student learning. While there is a growing body of research on 1:1 mobile devices, including the iPad in K-12 schools, there is little research on the potential of iPads to reduce the disparity of access to high-quality instruction and technology experienced by low income, racially and linguistically diverse students.

This three-year, mixed-method study investigated the degree to which a 1:1 iPad initiative in a high poverty, diverse urban high school reduced the disparity of technology access and instructional use and improved student learning across race, class, gender, and academic needs. The technology initiative at Urban High School (pseudonym) was designed to improve access to technology tools and resources and result in improved student attendance and academic achievement by providing an iPad to each student. The study focused on four research questions:

$R Q 1$. What factors influenced student technology access?

$R Q 2$. What factors influenced students' experience and use of technology? 
RQ3. How did students use iPads in the classroom?

RQ4. What was the impact of access to an iPad on students' attendance and GPA?

The analysis in this paper builds on previously reported research from the initial year of the study (Thieman, 2014).

\section{Literature}

The District (2010) in this study cited the iPad's affordability, ease of use, free and low-cost educational applications and versatility in its grant application[1], justifying its 1:1 iPad investment as a way to address the digital divide in a school where "nearly $80 \%$ of the students qualify for free and reduced lunch, 30\% meet the federal definition of homeless, $68 \%$ are from an identified minority group, and only $37 \%$ are completing the necessary credits for graduation" (p. 5). Using an iPad enables students to view teacher-created instructional materials and videos, manipulate and annotate text, take notes, communicate with the teacher, collaborate, create and publish content online. Teachers can monitor student progress and control content-specific applications to meet students' instructional needs (Perry and Steck, 2015).

\section{The digital divide}

To date, there is little research on how iPads can narrow the digital divide in high-quality technology instruction and access experienced by low income, racially and linguistically diverse students (Cotton et al., 2011; Dolan, 2016). Johnson et al. (2013) forecasted mobile learning as a "near-term horizon" technology to have a large impact and mainstream use in K-12 education and cited the importance of access to these devices as the equalizer for low income students. According to the US Department of Education, Office of Educational Technology (2016), "a digital use divide continues to exist between learners who are using technology in active, creative ways to support their learning and those who predominantly use technology for passive content consumption" (p. 5). While this study focuses on a 1:1 iPad initiative, much of the literature on instructional use of digital devices includes other mobile devices as well as laptops.

Despite near universal access to high-speed internet connections in most public school classrooms (NCES, 2011), the digital divide between the instructional opportunities for students in low and high socio-economic status (SES) classrooms remains. The socio-economic status of students is a key factor in the gap in how technology is actually used by teachers and students (Banister and Reinhart, 2011; Reinhart et al., 2011). Researchers found the curriculum and technology taught by teachers in higher SES schools was more intellectually rigorous and provided more opportunity for students to engage in creativity and higher-order thinking such as problem solving and data analysis than curriculum in lower SES schools (DeWitt, 2007; Valdez and Duran, 2007) where teachers tended to use technology for direct instruction (Boser, 2013; Ritzhaupt et al., 2016).

\section{The impact of technology on student learning}

More research is also needed on the potential of technology and its measureable impact on K-12 student learning. According to recent federal guidelines (US Department of Education, Office of Educational Technology, 2016), the ultimate result of technology integration must be an increase in student achievement. Despite the accelerating purchase of iPads for use in K-12 schools (Cavanagh, 2014), there has been little rigorous, long-term scholarship on the effectiveness of iPads for learning and teaching (Government of Alberta Minister of Education, 2011; Sung et al., 2016; Zheng et al., 2016). Norris et al. (2012) examined 1:1 laptop initiatives and reported that when computing devices are used as "essential" curriculum 
tools, student achievement increased; however, when the devices are "supplemental" there is no impact on student learning. Most of the research on 1:1 iPad initiatives in K-12 education focuses on teacher reports of instructional applications of iPads and student reports of engagement and satisfaction (NAACE, 2012; Reid and Ostashewski, 2011; Virginia Department of Education, 2011; Sung et al., 2016). According to a large study of 1:1 initiatives in 19 European countries, "only a very few identified improved learning outcomes as a project rationale" (Balanskat et al., 2013, p. 19). However, in a more recent meta-analysis of ten studies on the impact of 1:1 laptop programs, Zheng et al. (2016) found significantly positive average effect sizes in English, writing, math, and science.

Five meta-analyses of published articles on mobile learning provide an overview of research findings in the last decade (Liu et al., 2014; Pollara and Broussard, 2011; Sung et al., 2016; Wu et al., 2012; Zheng et al., 2016). Most of the studies were exploratory and conducted on a small scale. Mobile phones, PDAs, and laptops were the most widely used devices, and the benefits included increased student achievement, productivity, motivation, and engagement. For example, using 1:1 mobile devices increased student and teacher communication resulting in student skill improvement (Hung et al., 2010; Zheng et al., 2016) and more positive student-teacher relationships and greater student motivation (Rau et al., 2008; Zheng et al., 2016). In one study, 1:1 tablets helped to reduce effects of socio-economic inequalities among elementary students (Ferrer et al., 2011). Using digital text with an iPad supported high poverty students' technological fluency and creation of more sophisticated learning products, provided differentiation for multiple learning styles, a more supportive reading experience and supported increased student engagement for racially diverse high school students (Lundy, 2013).

\section{Methodology}

The research design involved concurrent and interactive quantitative and qualitative data (Creswell and Plano Clark, 2011) on the impact of providing an iPad to 1,075 students at Urban High School. Quantitative data sources included student technology experience and use surveys, conducted at the beginning and end of the school year (Appendix 1); classroom iPad use surveys conducted throughout the year (Appendix 2); and confidential student data including demographics, identified academic needs, attendance and GPA. Qualitative data, including three teacher focus groups (Appendix 3) and 29 classroom observations, confirmed and contextualized the survey data and are not detailed in this paper.

\section{Participants}

The sample includes all possible students who were eligible to receive 1:1 iPads over three years. Implementation of the 1:1 iPad program was different each year in terms of iPad access among students across grade levels, timing of distribution, and professional development for teachers in instructional use of iPads. Thus, the analysis focuses on three grade level cohorts totaling 1,075 students. Cohort A entered as 9th graders $(n=412)$ in 2012-2013, continuing as tenth graders (2013-2014) and 11th graders (2014-2015). Cohort B entered as 10th graders $(n=305)$ in 2012-2013, continuing as 11th graders (2013-2014) and 12th graders (2014-2015). Cohort $\mathrm{C}$ entered 9th grade $(n=358)$ in 2013-2014, continuing as 10th graders (2014-2015).

The participants in this study were predominantly eligible for free/reduced lunch (87 percent), students of color (71 percent), English speakers (64 percent), and male (56 percent). In total, 21 percent received special education services while 30 percent of the students were identified as English learners (Table I).

\section{Procedures and data collection}

One of the requirements of the district's grant funding was to determine the impact of the 1:1 iPad project on students' access, experiences, and use of technology: students' attendance 
Student

characteristic

Cohort A (9th: 2012-2013) Cohort B (10th: 2012-2013) Cohort C (9th: 2013-2014) Total

\section{Gender}

Female

Male

177

Total

410

145

180

325

161

195

356

483

Race/Ethnicity

Latino

123

Black

AIAN

API

Multi-racial

100

6

23

White

22

Total

127

401

100

67

9

24

16

83

Home language

English

Spanish

Other

Total

287

78

37

402

299

English learner

No

304

Yes 108

Total 412

Special education

No

315

Yes

97

Total

412

177

74

48

299

136

359

65

4

21

29

101

356

608
1,091

Free/Reduced lunch

No

56

Yes 356

412

207

98
305

221

101

33

355

Table I.

Notes: AIAN, American Indian/Alaska Native; API, Asian and Pacific Islander

THP ever?

and GPA; and teachers' attitudes toward and use of technology for instruction. The researcher explained the purpose of the research project to Urban High School teachers, asking for their cooperation with student survey administration, inviting them to participate in a teacher focus group, and asking permission to observe student iPad use in classrooms.

\section{Demographic data}

The district provided confidential education data including student identification number, demographics, home language, special education status, GPA, and attendance rates. Incomplete district data were later matched to state data for the analyses.

Student technology experience and use survey

Students completed the online Student Technology Experience and Use Survey (Appendix 1) at the beginning and end of the school year in their classrooms, including 
self-report of overall proficiency and satisfaction with use of the iPad. Student experiences included questions on the helpfulness and ease of using the iPad for academic tasks at school, and the frequency of iPad use at school and at home for various tasks. Responses were reported on a four-point Likert scale. The percent of students who completed the survey at least once ranged from 54 percent $(n=306)$ in 2012-2013, to 68 percent $(n=668)$ in 2013-2014, and 30 percent $(n=245)$ in 2014-2015.

\section{Classroom iPad use survey}

Beginning in January, 2013, Urban High School teachers were encouraged to have students complete a brief online survey of their iPad use at the end of each class when iPads were used for instruction (Appendix 2). The survey included 32 different iPad applications and 16 purposes for using the iPad in class. Students checked each of the iPad applications they used during the period and the purpose of using the technology, such as reading, writing, doing research, creating presentations, and accessing references. In year 1, 167 students completed the Classroom iPad Use Survey at least once (response rate, 29 percent; 664 surveys). In year 2, 305 students completed the survey at least once (response rate, 35 percent; 1,280 surveys). These 1,944 surveys provide only a snapshot of how some students used iPads. When conducting classroom observations, the researchers noted that frequently students might use iPads for classwork but did not complete the survey.

\section{Teacher focus groups}

In spring of 2013 and 2014, 11 teachers representing English, ESOL, math, science, social studies, and technology participated in three separate 60-90 minutes focus groups (Appendix 3) after school. Five of the teachers were considered by the school administrator and technology TOSA to be early technology adopters who had explored and used iPads in a variety of ways with their students. Each confidential focus group was taped and transcribed. Questions included strengths and limitations of the iPad project; potential impact on student engagement, learning, behavior, and attendance; and the extent to which the project reduced disparity of access and promoted differentiation.

\section{Classroom observations}

In total, 29 observations were conducted in 14 classrooms. Observation notes focused on the teacher and student role in each major activity, paying attention to when and how the teachers and/or students were using iPads or other technology. Classroom observation data provide context for the student surveys and teacher focus group data and are not reported in detail here.

Data analysis procedures. In addition to standard tests of differences ( $\chi^{2}, t$-tests), linear and logistic regressions were conducted for cross-sectional analyses, and longitudinal HLM analyses (linear and logistic) were conducted for analyses with three years of data.

$R Q 1$ investigated the factors that influenced student access to technology each year and across three years. $\chi^{2}$ analyses were conducted to determine if there were significant differences by grade level, gender, race/ethnicity, home language, and identified academic needs between the two student groups: those who checked out a Take Home iPad (THP) and those who did not. Logistic regression was used to assess the odds of a student having a THP in each year controlling for demographics and academic needs; linear regression predicted factors associated with more years of THP access.

$R Q 2$ explored the influence of having a THP on students' technology experience and use (Appendix 1). The researchers hypothesized that students who were assigned a THP and could use it throughout the school day and at home would report greater satisfaction, proficiency, ease of use, and helpfulness of the iPad than students who could only use 
technology in the classroom when prompted by the teacher. A $t$-test was used to compare the means for the two groups to determine if the differences reported on the survey were statistically significant. Logistic regression was conducted to predict the odds of student satisfaction and frequency of using the iPad outside of school, after controlling for THP status, student demographics and academic needs.

$R Q 3$ investigated the hypothesis that students who were assigned a THP would report greater use of iPads in their classes, using more applications and for a greater variety of purposes. The researchers created an index of the number of reported technology applications and an index of the number of iPad uses on the Classroom iPad Use Survey (Appendix 2). A $t$-test was used to compare the means for the two groups to determine if the differences in technology use reported by students who had a THP and those who did not were statistically significant. After controlling for demographic and special program categories, technology use data were regressed on technology app index and the technology use index each year.

$R Q 4$ examined the influence of access to a THP on students' attendance and GPA. The researchers hypothesized that students who were assigned a THP and could use it throughout the school day and at home would have a higher GPA and higher attendance rate than did students who could only use technology in the classroom when prompted by a teacher. A series of $t$-tests compared the means for the two groups to determine if the differences in average attendance rate and GPA between students who had a THP and those who did not were statistically significant. Regression analysis explored the relationship between THP access, attendance, and GPA while controlling for demographic and special program categories.

\section{Results}

Equity of student access to technology

Distribution of 1:1 iPads differed each of the three years due to changing requirements and staff availability to support iPad checkout, differences in communication with parents and students, and administrative support. In the first year, only 30 percent of the ninth and tenth grade students (169) were assigned a THP; the remaining 70 percent were assigned an iPad on a cart in one of the humanities classes for use at teacher discretion. In the second year, iPad distribution was timely and well organized; 43 percent (458) of 9th through 12th graders had a THP to use at school and at home. Similarly, in 2014-2015, 43 percent (437) of students checked out a THP.

$R Q 1$ examines the factors that influenced student access to technology. The district's goal was for every student to have a THP that could be used by the student throughout the school day and at home. Students who lacked parent permission/fee payment for the THP could use an iPad in the classroom, when directed to do so by the teacher. Students who were eligible for free/reduced lunch could request a fee waiver, but parent permission was still a requirement to checkout a THP. According to the special education case manager, access to a 1:1 iPad was frequently provided in students' IEPs. Statistical analysis was conducted to determine if there were significant differences each year between the two groups (students with and without a THP) by grade level, gender, race/ethnicity, home language, poverty rate, special education status, and enrollment stability. Table II shows that equitable access to a THP was inconsistent.

There were significant differences in iPad access. In all three years, ninth graders were statistically more likely to have a THP than tenth graders. In years 2 and 3 , white students and those identified as academic priority (a district category and proxy for poverty) were statistically more likely to have a THP.

Logistic regression was used to assess the odds of having a THP each year after controlling for student demographics, special program status, and enrollment stability (Table III). 


\begin{tabular}{|c|c|c|c|c|c|}
\hline Student category & THP & No THP & $\chi^{2}$ & $p$-value & \\
\hline \multicolumn{6}{|l|}{$2012-2013(n=573)$} \\
\hline \multicolumn{6}{|l|}{ Grade } \\
\hline 9 th & $110(34 \%)$ & $212(66 \%)$ & & & \\
\hline 10 th & $59(24 \%)$ & $192(76 \%)$ & $\chi^{2}(1)=7.70$ & 0.006 & \\
\hline \multicolumn{6}{|l|}{$2013-2014(n=1,070)$} \\
\hline \multicolumn{6}{|l|}{ Grade } \\
\hline 9th & $215(64 \%)$ & $120(36 \%)$ & & & \\
\hline 10th & $125(40 \%)$ & $190(60 \%)$ & & & \\
\hline 11th & $107(49 \%)$ & $113(51 \%)$ & & & \\
\hline 12 th & $11(5 \%)$ & $189(95 \%)$ & $\chi^{2}(3)=180.51$ & $<0.001$ & \\
\hline \multicolumn{6}{|l|}{ Gender } \\
\hline Female & $218(47 \%)$ & $242(53 \%)$ & & & \\
\hline Male & $240(41 \%)$ & $348(59 \%)$ & $\chi^{2}(1)=4.53$ & 0.033 & \\
\hline \multicolumn{6}{|l|}{ Race/Ethnicity } \\
\hline White & $157(50 \%)$ & $159(50 \%)$ & & & \\
\hline Non-white/Hisp & $301(41 \%)$ & $433(59 \%)$ & $\chi^{2}(1)=6.76$ & 0.009 & \\
\hline \multicolumn{6}{|l|}{ Academic priority } \\
\hline Yes & $307(50 \%)$ & $308(50 \%)$ & & & \\
\hline No & $151(34 \%)$ & $293(66 \%)$ & $\chi^{2}(1)=39.02$ & $<0.001$ & \\
\hline \multicolumn{6}{|l|}{$2014-2015(n=1,010)$} \\
\hline \multicolumn{6}{|l|}{ Grade } \\
\hline 9 th & $148(57 \%)$ & $111(43 \%)$ & & & \\
\hline 10th & $144(50 \%)$ & $143(50 \%)$ & & & \\
\hline 11th & $88(36 \%)$ & $157(64 \%)$ & & & \\
\hline 12 th & $57(26 \%)$ & $162(74 \%)$ & $\chi^{2}(3)=57.80$ & $<0.001$ & \\
\hline \multicolumn{6}{|l|}{ English learner } \\
\hline Not EL & $402(46 \%)$ & $476(54 \%)$ & & & \\
\hline EL & $35(27 \%)$ & $97(73.5 \%)$ & $\chi^{2}(1)=17.36$ & $<0.001$ & \\
\hline \multicolumn{6}{|l|}{ Race/Ethnicity } \\
\hline White & $140(56 \%)$ & $111(44 \%)$ & & & \\
\hline Non-white/Hispanic. & $272(37 \%)$ & $451(62 \%)$ & $\chi^{2}(1)=25.16$ & $<0.001$ & Table II. \\
\hline Academic priority & & & & & Assignment of Take \\
\hline Yes & $198(54 \%)$ & $171(46 \%)$ & & & Home iPads (THP) \\
\hline No & $239(37 \%)$ & $402(63 \%)$ & $\chi^{2}(1)=25.58$ & $<0.001$ & by student category \\
\hline
\end{tabular}

\begin{tabular}{|c|c|c|c|c|}
\hline \multirow[b]{2}{*}{ Variable } & \multicolumn{3}{|c|}{ All years ( $n=1,270,2,393$ observations) } & \\
\hline & OR & $\mathrm{SE}$ & $p$-Value & \\
\hline Female & $1.61(1.15,2.24)$ & 0.272 & $p<0.01$ & \\
\hline English speaking & $1.01(0.70,1.46)$ & 0.189 & & \\
\hline Grade & $0.71(0.61,0.81)$ & 0.051 & $p<0.001$ & \\
\hline Free/Reduced lunch & $1.82(1.30,2.53)$ & 0.308 & $p<0.001$ & \\
\hline Special education status & $1.07(0.72,1.58)$ & 0.216 & & \\
\hline White & $2.10(1.41,3.12)$ & 0.423 & $p<0.001$ & \\
\hline Stability & $2.21(1.59,3.07)$ & 0.373 & $p<0.001$ & Table III. \\
\hline \multirow{2}{*}{$\begin{array}{l}\text { Log likelihood } \\
\text { Model significant }\end{array}$} & \multirow{2}{*}{\multicolumn{3}{|c|}{ Wald (design) $\gamma^{2(7)}=83.74,-1,336.641$}} & Access to a THP \\
\hline & & & & across all three years \\
\hline
\end{tabular}

Across all three years, females, ninth graders, white students, those eligible for free/reduced lunch, and those with no school enrollment changes during the school year were more likely to have access to a THP. Linear regression predicted the factors associated with more years of access to THP; four variables were significant. Students who were white 
$(b=0.209, p=<0.01)$; high poverty $(b=0.235, p=<0.001$; English speakers $(b=0.177$, $p<0.01)$ ) and students with stable enrollment at Urban High School had more years of access to a THP $(b=0.366, p=<0.001)$.

\section{Student technology experience and use}

$R Q 2$ focuses on student responses to the student technology experience and use survey (Appendix 1) administered at the beginning and end of each year $(n-1,219)$.

The survey included self-report of overall proficiency, satisfaction and use of the iPad for various academic tasks. A test of difference was used to compare the means for the two groups to determine if the differences between students who had a THP and those who did not were statistically significant.

Table IV indicates that in all three years, students with a THP had significantly higher mean scores for satisfaction and proficiency with technology, helpfulness of the iPad for doing academic tasks, and greater frequency of iPad use outside of school for academic tasks than students without an individually assigned iPad. In the second and third years of the study students with a THP also had significantly higher mean scores for ease of use of the technology, and greater frequency of use of the iPads than students without a THP.

Logistic regression confirmed that across all years students having THP access during the year, compared to those who did not, were more likely to have more positive attitudes

\begin{tabular}{|c|c|c|c|c|c|c|}
\hline & $\begin{array}{c}\text { THP } \\
\text { status }\end{array}$ & $n$ & Mean & $\mathrm{SD}$ & $t$-Test & $p$-value \\
\hline \multicolumn{7}{|l|}{$2012-2013(n=306)$} \\
\hline \multirow[t]{2}{*}{ Technology satisfaction/Proficiency (1 low-8 high) } & No & 190 & 6.56 & 1.29 & $t(304)=-4.75$ & $<0.001$ \\
\hline & Yes & 116 & 7.19 & 0.79 & & \\
\hline \multirow[t]{2}{*}{ Helpfulness (1 low-28 high) } & No & 190 & 21.48 & 4.57 & $t(304)=-3.04$ & 0.003 \\
\hline & Yes & 116 & 23.02 & 3.76 & & \\
\hline \multirow[t]{2}{*}{ Frequency of iPad use outside school (1 low-32 high) } & No & 190 & 19.51 & 7.62 & $t(304)=-2.30$ & 0.022 \\
\hline & Yes & 116 & 21.53 & 7.17 & & \\
\hline \multicolumn{7}{|l|}{$2013-2014(n=668)$} \\
\hline \multirow[t]{2}{*}{ Technology satisfaction/Proficiency (1 low- 8 high) } & No & 300 & 6.47 & 1.40 & $t(666)=-6.10$ & $<0.001$ \\
\hline & Yes & 368 & 7.03 & 0.97 & & \\
\hline \multirow[t]{2}{*}{ Ease of use (1 low-32 high) } & No & 300 & 25.64 & 5.28 & $t(666)=-3.94$ & $<0.001$ \\
\hline & Yes & 368 & 26.98 & 3.46 & & \\
\hline \multirow[t]{2}{*}{ Helpfulness (1 low-28 high) } & No & 300 & 20.77 & 5.38 & $t(666)=-4.12$ & $<0.001$ \\
\hline & Yes & 368 & 22.22 & 3.70 & & \\
\hline \multirow[t]{2}{*}{ Frequency of iPad use inside school (1 low- 4 high) } & No & 300 & 2.19 & 0.85 & $t(666)=-8.06$ & $<0.001$ \\
\hline & Yes & 368 & 2.69 & 0.74 & & \\
\hline \multirow[t]{2}{*}{ Frequency of iPad use outside school (1 low-32 high) } & No & 300 & 19.54 & 7.58 & $t(666)=-7.28$ & $<0.001$ \\
\hline & Yes & 368 & 23.11 & 5.00 & & \\
\hline \multicolumn{7}{|l|}{$2014-2015(n=245)$} \\
\hline \multirow[t]{2}{*}{ Technology satisfaction/Proficiency (1 low-8 high) } & No & 118 & 6.37 & 1.42 & $t(243)=-4.02$ & $<0.001$ \\
\hline & Yes & 127 & 6.99 & 0.99 & & \\
\hline \multirow[t]{2}{*}{ Ease of use (1 low-32 high) } & No & 118 & 25.67 & 5.63 & $t(243)=-2.67$ & $<0.001$ \\
\hline & Yes & 127 & 27.26 & 3.51 & & \\
\hline \multirow[t]{2}{*}{ Helpfulness (1 low-28 high) } & No & 118 & 20.32 & 5.49 & $t(243)=-2.32$ & 0.021 \\
\hline & Yes & 127 & 21.72 & 3.84 & & \\
\hline \multirow[t]{2}{*}{ Frequency of iPad use inside school (1 low-4 high) } & No & 118 & 2.15 & 0.90 & $t(243)=-3.77$ & 0.0002 \\
\hline & Yes & 127 & 2.54 & 0.71 & & \\
\hline \multirow[t]{2}{*}{ Frequency of iPad use outside school (1 low-32 high) } & No & 118 & 20.03 & 7.58 & $t(243)=-2.54$ & 0.012 \\
\hline & Yes & 127 & 22.16 & 5.44 & & \\
\hline
\end{tabular}

Table IV.

Technology satisfaction/ proficiency, helpfulness, and frequency of use compared to iPad assignment 
$(\mathrm{OR}=2.0(1.41,2.91))$, greater ease of technology use $(2.0(1.40,3.02))$, find iPads more helpful for academic tasks $(\mathrm{OR}=1.7(1.17,2.35))$, use technology more frequently in school $(\mathrm{OR}=3.4(2.46,4.77))$, and out of school $(\mathrm{OR}=2.2(1.55,3.05))$, after controlling for demographics, identified academic needs, and enrollment stability at Urban High School.

\section{Student use of iPads in school}

$R Q 3$ examines how students used iPads in the classroom based on their response to the Classroom iPad Use Survey. Students reported using 32 different applications: the top seven types were web browsers; Google tools; learning management systems, presentation tools; note taking applications; and assessment applications. Students reported 16 purposes for using their iPads. Doing research and accessing references was reported most frequently, followed by reading, writing, taking notes, listening to music, and watching videos. Students also reported creating multimedia presentations and to a lesser extent working on collaborative projects. They reported using their iPads to solve math or science problems or communicate by e-mail less often.

In both years, students who had a THP reported mores uses of technology in school.

Classroom observations indicated that in a 90-minute class period students often received direct instruction, collaborated with peers in a discussion or problem-solving activity and occasionally used iPads to support and differentiate their learning through online instruction. Students accessed teacher webpages to view short informational videos and were able to work at their own pace. They could follow links for definitions and more detailed information, highlight and take notes in the online texts (Table V).

A $t$-test indicated a statistically significant difference between students who had a THP and those who did not. The mean technology application index for students with a THP was twice that of students who did not have a THP and could only use an iPad from the classroom cart in 2012-2013, and 43 percent greater for students with a THP in 2013-2014. Similarly, in 2012-2013, the mean technology use index for students with a THP was 85 percent greater and 75 percent greater in 2013-2014 than for students without a THP. Clearly students who had a THP and completed the Classroom iPad Use Survey reported a significantly greater opportunity to use technology for learning.

Linear regression predicted the factors associated with higher technology application and use indexes when controlling for THP access, demographics, and identified academic needs. In both years, linear regression indicated access to a THP was associated with a higher technology application index; 2012-2013: $(b=0.824, p=<0.01)$ and 2013-2014: $(b=0.566, p=<0.01)$.

\begin{tabular}{|c|c|c|c|c|c|c|}
\hline & $n$ & Mean & SD & $t$-Test & Sig. & \\
\hline \multicolumn{7}{|c|}{$2012-2013(n=165)$} \\
\hline \multicolumn{7}{|c|}{ Tech app index } \\
\hline No THP & 100 & 2.17 & 1.92 & & & \\
\hline THP & 67 & 4.58 & 4.74 & $t(165)=-4.57$ & $p=<0.001$ & \\
\hline \multicolumn{7}{|l|}{ Tech use index } \\
\hline No THP & 100 & 5.30 & 4.70 & & & \\
\hline THP & 67 & 9.82 & 12.35 & $t(165)=-3.32$ & $p=0.001$ & \\
\hline \multicolumn{7}{|c|}{$2013-2014(n=305)$} \\
\hline No THP & 124 & 3.61 & 6.11 & & & \\
\hline THP & 181 & 5.19 & 6.45 & $t(303)=-2.14$ & $p=0.03$ & Technology \\
\hline Tech use index & & & & & & applications and use \\
\hline No THP & 124 & 3.73 & 5.11 & & & in school compared \\
\hline THP & 181 & 6.55 & 7.81 & $t(303)=-3.54$ & $p=0.001$ & to iPad assignment \\
\hline
\end{tabular}


Linear regression also indicated access to a THP was significantly associated with a higher technology use index in 2012-2013 $(b=0.606, p=<0.01)$ and in 2013-2014 $(b=0.719, p=<0.001)$.

Despite the large number of technology use surveys (1944), in both years there was a major problem of selection bias. A minority of teachers accounted for the majority of student surveys, and these tended to be the early adopters who had explored and used iPads in a variety of ways with their students. The surveys were not conducted in 2014-2015 due to lack of administrative and teacher support for the survey.

\section{Impact of access to iPads on student learning}

$R Q 4$ examined the impact of access to a THP on students' attendance and GPA each year and across all three years of the study. Table VI presents the mean attendance rate of students with and without a THP each year.

In all three years, students with a THP had a significantly higher attendance rate (85-91 percent) that was three to seven percentage points higher than students without a THP. After controlling for student demographics, identified academic needs, and enrollment stability across all three years, the odds of students with access to THP attending school at least 90 percent of the time was twice that of students without THP access $(\mathrm{OR}=2.0(1.51,2.76))$ after controlling for demographic characteristics, identified special needs, and enrollment stability.

Table VII presents the mean GPA of students with and without a THP each year. In all three years, students with a THP had a slightly higher GPA (0.33-0.63 on a four-point scale) than students without a THP.

Linear regression predicted the influences on GPA across all three years. Controlling for demographics, identified academic needs, and enrollment stability at Urban High School, access to a THP was significant in 2012-2013 $(b=0.437, p<0.001)$ and in 2013-2014 $(b=0.159, p=<0.05)$. However, the impact of iPad access on GPA was not significant in $2014 / 2015$ or across all three years.

\section{Discussion and conclusions}

Both the district and high school staff intended for the 1:1 iPad project to improve the quality of technology tools and reduce the disparities in technology access and instruction

Table VI.

Mean attendance rate by year compared to THP status

\begin{tabular}{lcccccc}
\hline & THP status & $n$ & Mean & SD & $t$-Test & Sig. \\
\hline Attendance rate by THP 2012-2013 & No & 424 & 85.72 & 13.93 & $t(613)=-4.96$ & $<0.001$ \\
& Yes & 191 & 91.22 & 9.49 & & \\
Attendance rate by THP 2013-2014 & No & 453 & 78.05 & 21.02 & $t(918)=-5.76$ & $<0.001$ \\
& Yes & 467 & 85.48 & 18.07 & & \\
Attendance rate by THP 2014-2015 & No & 550 & 83.52 & 19.53 & $t(984=-4.31)$ & 0.011 \\
& Yes & 436 & 86.72 & 19.84 & & \\
\hline
\end{tabular}

Table VII.

Mean GPA by year compared to THP status

\begin{tabular}{|c|c|c|c|c|c|c|}
\hline & THP status & $n$ & Mean & $\mathrm{SD}$ & $t$-Test & Sig. \\
\hline \multirow[t]{2}{*}{ GPA by THP 2012-2013 } & No & 360 & 2.10 & 1.13 & \multirow[t]{2}{*}{$t(525)=-6.13$} & \multirow[t]{2}{*}{$<0.001$} \\
\hline & Yes & 167 & 2.73 & 1.01 & & \\
\hline \multirow[t]{2}{*}{ GPA by THP 2013-2014 } & No & 288 & 2.13 & 1.01 & \multirow[t]{2}{*}{$t(693)=-4.09$} & \multirow[t]{2}{*}{$<0.001$} \\
\hline & Yes & 407 & 2.46 & 1.04 & & \\
\hline \multirow[t]{2}{*}{ GPA by THP 2014-2014 } & No & 188 & 2.36 & 0.94 & \multirow[t]{2}{*}{$t(577)=-4.31$} & \multirow[t]{2}{*}{$<0.001$} \\
\hline & Yes & 391 & 2.70 & 0.91 & & \\
\hline
\end{tabular}


among low income students by providing every ninth and tenth grade students an individual iPad in 2012-2013 and every 9th through 12th grader a THP in 2013-2015. Despite efforts to increase the number of Urban High School students who had a THP, the percentage never rose above 43 percent.

The effects of technology on instruction are most likely when each student has access to an individual digital device (Warschauer, 2006). In order for students to benefit from 24/7 access to technology, each must have a mobile device. Unfortunately, the district underestimated the challenge of ensuring that every student would have an individually assigned iPad. Initial communication with families focused on the financial and legal obligations associated with the iPads but did not emphasize the benefits of the iPads to support student learning during and after school. A key requirement for successful implementation is outreach to families within the school community, and neither the district or school administration seemed to follow Schnellert and Keengwe's (2012) advice: "Selling is better than telling. Everyone needs to buy into the change that technology brings" (p. 42).

A major focus of the research was to identify the degree to which iPads were distributed equitably across demographic and academic needs categories. The final results on access to a THP were mixed. In each of the three years, ninth graders were more likely to have an individual iPad. Teachers commented in the focus groups that having their own iPad was both a novelty and a perceived status symbol for freshman. Across all three years students eligible for free/reduced lunch were more likely to have a THP. This is a positive outcome of the district and school attention to students who live in poverty.

However, students of color were less likely to have a THP than white students. From a social justice perspective and given the district and school emphasis on "all students by name are prepared for college, career and participation as an active community member, regardless of race, income or zip code" (District, 2014), this is troubling. While the majority of students of color were also eligible for free/reduced lunch and potentially more likely to have a THP, when THP access data were disaggregated by race/ethnicity alone, these students were less likely to have a THP. Teachers commented in focus groups that some students of color were living in precarious environments and did not feel safe taking an iPad home. The technology TOSA also explained that school administrators had not communicated the importance of the 1:1 iPad initiative to families, least of all families of color.

The importance of this digital divide in access was clearly shown in the student surveys when students with a THP reported significantly higher proficiency, ease of use and helpfulness of technology for academic tasks than those who did not. When controlling for THP access all years, students with a THP reported higher scores for using technology in school and outside of school for academic purposes than those without a THP. This finding is confirmed by research studies reported by Zheng et al. (2016) about higher student engagement, motivation, and persistence in one-to-one digital environments.

The benefits of having a THP also stood out in analyzing the impact of the 1:1 iPad project on attendance and GPA. In all three years, students with a THP had a higher attendance rate than students without a THP. While not significant across all three years, the mean GPA of students with a THP was 0.33-0.63 higher than students without a THP. Previous research into empirical studies of laptop programs by Bebell and O'Dwyer (2010) discovered significant increases in GPA relative to schools without such programs.

Several barriers to successful technology integration identified by Schnellert and Keengwe (2012) were prominent at Urban High School: inconsistent administrative support, ambivalent staff attitudes and unfamiliarity with curricular applications of iPads, and lack of technical support. The original grant that funded the 1:1 iPad project at Urban High School was written by a district administrator and did not include funding for ongoing technology training. The high school principal was not perceived to be actively involved in communicating the educational importance of the technology initiative to families or teachers. 
The year after the iPad grant funding ended, the initial administrators who supported the project left the district, and the 1:1 iPad project ceased. Urban High School's experience is similar to research by Warschauer et al. (2011) that found an externally mandated 1:1 program with minimal funding for curriculum development, infrastructure support, and teacher professional development did not result in positive changes, and the 1:1 program was abandoned after three years.

While the majority of Urban High School teachers reported in a 2012 district survey they were familiar with iPads, felt comfortable integrating technology into their classrooms and did so at least weekly, the classroom iPad use surveys and observations painted a different picture. The majority of the 1,944 surveys were completed in seven teachers' classrooms; many of these teachers were considered to be early adopters of technology. However, as Norris et al. (2012) suggest, instructional use of computing devices, e.g. iPads, needs to be an essential curriculum tool that enables students to learn on a daily basis in ways that are not well supported through traditional instruction. The teacher focus groups and classroom observations suggest that only a few teachers substantively integrated iPads into daily instructional practice at the high school.

In the focus groups, teachers expressed reluctance to devoting time to develop instructional technology activities for students when the majority did not have 1:1 iPads. Teachers commented that since a majority of students did not have a THP and they perceived (incorrectly) that a majority of students did not have a home computer or internet access, they were less likely to assign frequent homework that required using a digital device. Instructional use of iPads varied considerably all three years and was never considered an essential tool by most teachers.

The National Education Technology Plan reaffirms, for technology "to be transformative, educators need to have the knowledge and skills to take full advantage of technology-rich learning environments" (USDOE, 2016, p. 3). The need for more technology professional development was a common refrain and substantiated other studies of technology adoptions (Banister and Fischer 2010; Cotton et al., 2011; Sung et al., 2016).

All too often, when schools mandate the use of a specific technology, teachers are left without the tools (and often skills) to effectively integrate the new capabilities into their teaching methods. The results are that the new investments are underutilized, not used at all, or used in a way that mimics an old process (Johnson et al., 2013, p. 9).

Teachers cited conflicting administrative expectations to participate in curriculum and assessment meetings that squeezed out time for technology training.

Research on successful technology integration is replete with recommendations: provide relevant, continuous, and timely professional development in small group and individual formats; provide adequate time for teachers to learn and integrate new technologies into their practice; provide high quality, timely technical support (Buckenmeyer, 2008). Ensminger and Surry (2008) and the International Society for Technology in Education (2012) emphasize the need for positive administrative expectations, supervision, and support at all levels; expectations that all students will have equitable access to the technology; and ongoing professional development for teachers in using the technology as an integral tool for student learning.

This research focuses on an issue of digital equity that has not yet been studied in depth with 1:1 iPads. Many of the schools and districts that have purchased 1:1 mobile devices for students to take home are private schools or public schools that serve upper middle class students. This case study looks in depth at students' access, experiences, and use of iPads to support student learning in a high poverty, highly diverse, urban high school and suggests the potential of 1:1 technology for promoting digital equity and improving student learning. Despite multiple challenges of inequitable distribution, limited professional development, inconsistent administrative support, and ambivalent teachers, access to and use of an individual iPad resulted in higher attendance and slightly higher GPA over three years for students who had a THP. 


\section{Note}

1. Portland State University provided the first author a $\$ 14,265.00$ Faculty Enhancement Grant for release time and Graduate Assistant support by the second author in 2013-2014. Mount Hood Cable Regulatory Commission provided $\$ 5,000$ to the Center for Student Success at Portland State University to support final year of data collection and analysis in 2014-2015. The authors wish to acknowledge the contribution of the staff of the Center for Student Success, Portland State University Graduate School of Education, in providing statistical analysis.

\section{References}

Balanskat, A., Bannister, D., Hertz, B., Sigillo, E. and Vuorikari, R. (2013), "Overview and analysis of 1:1 learning initiatives in Europe", Joint Research Centre Institute for Prospective Technological Studies, available at: http://jrc.es/pub/EURdoc/JRC81903.pdf

Banister, S. and Fischer, J. (2010), "Overcoming the digital divide: the story of an urban middle school", Mid-Western Educational Researcher, Vol. 23 No. 2, p. 2.

Banister, S. and Reinhart, R. (2011), "TPCK for impact: classroom teaching practices that promote social justice and narrow the digital divide in an urban middle school", Computers in the Schools, Vol. 28 No. 1, pp. 5-26.

Bebell, D. and O'Dwyer, L. (2010), "Educational outcomes and research from 1:1 computing settings", Journal of Technology, Learning and Assessment, Vol. 9 No. 1, pp. 5-15.

Boser, U. (2013), “Are schools getting a big enough bang for their education technology buck?”, Center for American Progress, available at: www.americanprogress.org/issues/education/report/ 2013/06/14/66485/are-schools-getting-a-big-enough-bang-for-their-education-technology-buck/ (accessed September 13, 2017).

Buckenmeyer, J. (2008), "Revising teacher adoption of technology: research implications and recommendations for successful full technology integration", College Teaching Methods and Styles Journal, Vol. 6 No. 4, pp. 7-10.

Cavanagh, S. (2014), "Apple touts strong iPad sales in global school market”, Ed Week Market Brief, available at: https://marketbrief.edweeka.org/marketplace-k-12/apple_boasts_of_surge_in_ worldwide_sales_of_ipads_for_education/(accessed September 13, 2017).

Cotton, S.R., Hale, T.M., Moroney, M.H., O’Neal, L. and Borch, C. (2011), "Using affordable technology to decrease digital inequality”, Information Communication \& Society, Vol. 14 No. 4, pp. 424-444, doi: 10.1080/1369118X.2011.559266.

Creswell, J.W. and Plano Clark, V.L. (2011), Designing and Conducting Mixed Methods Research, 2nd ed., SAGE Publications, Los Angeles, CA.

DeWitt, S.W. (2007), "Dividing the digital divide: instructional use of computers in social studies", Theory and Research in Social Education, Vol. 35 No. 2, pp. 277-304.

District (2010), "Technology immersion pilot: building the blueprint for our future", Grant application submitted to Mt. Hood Cable Regulatory Commission.

District (2014), "PPS strategic framework", available at: www.pps.net/Page/2321

Dolan, J. (2016), "Splicing the divide: a review of research on the evolving digital divide among K-12 students", Journal of Research on Technology in Education, Vol. 48 No. 1, pp. 16-37, doi: 10.1080/ 15391523.2015.1103147.

Ensminger, D.C. and Surry, D.W. (2008), "Relative ranking of conditions that facilitate innovation implementation in the USA", Australasian Journal of Educational Technology, Vol. 24 No. 5, pp. 611-626.

Ferrer, F., Belvis, E. and Palmes, J. (2011), "Tablet PCs, academic results, and educational inequalities", Computers and Education, Vol. 56 No. 1, pp. 280-288, doi: 10.1016/j.compedu.2010.07.018.

Government of Alberta Minister of Education (2011), "iPads-what are we learning? Summary report of provincial data gathering day", available at: https://education.alberta.ca/media/6684652/ipad\% 20report \%20-\%20final\%20version \%202012-03-20.pdf 
Hung, P.-H., Lin, Y.-F. and Hwang, G.-J. (2010), "Formative assessment design for PDA integrated ecology observation", Journal of Educational Technology \& Society, Vol. 13 No. 3, pp. 33-42.

International Society for Technology in Education (2012), "Essential conditions", available at: www.iste.org/standards/essential-conditions (accessed September 13, 2017).

Johnson, L., Adams Becker, S., Cummins, M., Estrada, V., Freeman, A. and Ludgate, H. (2013), "NMC horizon report: 2013-K-12”, The New Media Consortium, Austin, TX.

Liu, M., Scordino, R., Geurtz, R., Navarrete, C., Ko, Y.-J. and Lim, M.-H. (2014), "A look at research on mobile learning in K-12 education from 2007 to present”, Journal of Research on Technology in Education, Vol. 46 No. 4, pp. 325-372.

Lundy, S. (2013), "Integrating digital technology in social studies education: a multiple-case study comparing the use of a digital and print text in high school social studies classes", unpublished doctoral dissertation, Portland State University, Portland, OR.

NAACE (2012), "The iPad as a tool for education: a study of the introduction of iPads at longfield academy, Kent", available at: www.naace.co.uk/publications/the-ipad-as-a-tool-for-education-acase-study/ (accessed September 13, 2017).

National Center for Education Statistics (NCES) (2011), "Digest of education statistics", US Department of Education, Washington, DC, available at: http://nces.ed.gov/programs/digest/d11/tables/ dt11_109.asp

Norris, C., Hossain, A. and Soloway, E. (2012), "Under what conditions does computer use positively impact student achievement? Supplemental vs essential use”, in Resta, P. (Ed.), Proceedings of Society for Information Technology \& Teacher Education International Conference 2012, AACE, Chesapeake, VA, pp. 2021-2028.

Perry, D.R. and Steck, A.K. (2015), "Increasing student engagement, self-efficacy, and meta-cognitive self-regulation in the high school geometry classroom: do iPads help?", Computers in the Schools, Vol. 32 No. 2, pp. 122-143, doi: 10.1080/07380569.2015.1036650.

Pollara, P. and Broussard, K.K. (2011), "Mobile technology and student learning: what does current research reveal?", International Journal of Mobile and Blended Learning, Vol. 3 No. 3, pp. 34-42.

Rau, P.-L., Gao, Q. and Wu, L.-M. (2008), "Using mobile communication technology in high school education: motivation, pressure, and learning performance", Computers and Education, Vol. 50 No. 1, pp. 1-22, doi: 10.1016/j.compedu.2006.03.008.

Reid, D. and Ostashewski, N. (2011), "iPads in the classroom - new technologies, old issues: are they worth the effort?", in Bastiaens, T. and Ebner, M. (Eds), Proceedings of World Conference on Educational Multimedia, Hypermedia and Telecommunications 2011, AACE, Chesapeake, VA, pp. 1689-1694.

Reinhart, J., Thomas, E. and Toriskie, J. (2011), "K-12 teachers: technology use and the second level digital divide", Journal of Instructional Psychology, Vol. 38 No. 3, pp. 181-193.

Ritzhaupt, A.D., Hohlfeld, T.N., Wilson, M. and Dawson, K.M. (2016), "A longitudinal study of the digital divide in Florida schools: beyond access", paper presented to the American Educational Research Association, Instructional Technology SIG, Washington, DC.

Schnellert, G. and Keengwe, J. (2012), "Digital technology integration in American public schools", International Journal of Information and Communication Technology, Vol. 8 No. 3, pp. 36-44.

Sung, Y., Chang, K.-E. and Liu, T.-C. (2016), "The effects of integrating mobile devices with teaching and learning on students' learning performance: a meta-analysis and research synthesis", Computers \& Education, Vol. 94, March, pp. 252-275.

Thieman, G.Y. (2014), "Challenges and opportunities in the first year of a 1:1 iPad initiative in a high-poverty, highly diverse urban high school”, in Heafner, T., Hartshorne, R. and Petty, T. (Eds), Exploring the Effectiveness of Online Education in K-12 Environments, IGI Global, Hershey, PA, pp. 257-285. 
US Department of Education, Office of Educational Technology (2016), "Future ready learning: reimagining the role of technology in education", US Department of Education, Office of Educational Technology, Washington, DC.

Valdez, J. and Duran, R. (2007), "Redefining the digital divide: beyond access to computers and the Internet”, High School Journal, Vol. 90 No. 3, pp. 31-44.

Virginia Department of Education (2011), "Beyond textbooks: year one report", Richmond, VA, May 24-26, available at: www.doe.virginia.gov/support/technology/technology_initiatives/ learning_without_boundaries/beyond_textbooks/year_one_beyond_textbooks_report.pdf (accessed September 13, 2017).

Warschauer, M. (2006), Laptops and Literacy: Learning in the Wireless Classroom, Teachers College Press, New York, NY.

Warschauer, M., Cotten, S. and Ames, M.G. (2011), "One laptop per child Birmingham: case study of a radical experiment”, International Journal of Learning and Media, Vol. 3 No. 2, pp. 61-76, doi: 10.1162/ijlm_a_00069.

Wu, W.-H., Jim, W.Y.-C., Chen, C.-Y., Kao, H.-Y., Lin, C.-H. and Huang, S.H. (2012), "Review of trends from mobile learning studies: a meta-analysis", Computers and Education, Vol. 59 No. 2, pp. 817-827, doi: 10.1016/j.compedu. 2012.03.016.

Zheng, B., Warschauer, M., Lin, C.-H. and Chang, C. (2016), "Learning in one-to-one laptop environments: a meta-analysis and research synthesis", Review of Educational Research, Vol. 84 No. 4, pp. 1052-1084, doi: 10.3102/0034654316628645.

(The Appendix follows overleaf.) 


\section{Appendix 1. Student technology experience and use survey}

High school staff asked students to follow a link on their iPad to complete the electronic survey at the beginning and end of the school year in $2012-13,2013-14$, and 2014-15.

What is your student ID number?

What grade are you in?

$$
\begin{array}{r}
9^{\text {th }} \\
-10^{\text {th }} \\
-11^{\text {th }} \\
-12^{\text {th }}
\end{array}
$$

What type of 1:1 technology have you been assigned? iPad,

Please rate your overall proficiency with use of the iPad:

1 Low to 4 High

Do you have a home computer?

$$
\text { Yes }
$$

No

Do you have Internet at home?

$$
\text { Yes }
$$

- No

Please rate your overall satisfaction with use of the [iPad] technology?

1 Low to 4 High

What were the strengths of using the iPad?

What were the challenges of using the iPad?

How often have you used your iPad during school?

in no classes

- in 1-2 classes a week

- in 3-5 classes a week

_ in every class during the week

For the next set of questions the choices were:

not helpful

somewhat helpful

_helpful

_ very helpful

How helpful is your iPad in doing the following: homework?

How helpful is your iPad in doing the following: writing assignments?

How helpful is your iPad in doing the following: communicating and collaborating?

How helpful is your iPad in doing the following: organizing schoolwork?

How helpful is your iPad in doing the following: doing research?

How helpful is your iPad in doing the following: accessing information?

How helpful is your iPad in doing the following: staying motivated and engaged? 
For the next set of questions the choices were:

very hard to use

hard to use

easy to use

_ very easy to use

How easy is it to use your iPad for the following: turning in homework?

How easy is it to use your iPad for the following: writing assignments?

How easy is it to use your iPad for the following: creating content?

How easy is it to use your iPad for the following: installing my own apps?

How easy is it to use your iPad for the following: adding my own music?

How easy is it to use your iPad for the following: taking care of the device?

How easy is it to use your iPad for the following: communicate (IM, email, video chat,

blog)

How easy is it to use your iPad for the following: connecting wirelessly at school?

Any other comments:

For the next set of questions the choices were:

never

once a week

2-3 times a week

- every day

How often do you use the iPad outside of school to? do homework

How often do you use the iPad outside of school? communicate (IM, email, video chat, blog)

How often do you use the iPad outside of school? Create videos, presentations, or projects

How often do you use the iPad outside of school? Find information

How often do you use the iPad outside of school? Watch videos

How often do you use the iPad outside of school? Play games

How often do you use the iPad outside of school? Listen to music

How often do you use the iPad outside of school? Use social media (Facebook, Twitter, etc.) 


\section{Appendix 2. Classroom iPad use survey}

High school staff asked students to follow a link on their iPad to complete the digital survey. Student Number:

Class Name:

Period:

1

2

3

4

5

6

7

After School

Which iPad Apps did you use during this period?

3D Game Lab

30 Hands

Adobe Reader

ATT Scanner

Bookabi

Class Website

Dragon Dictation

Dropbox

Edmodo

Educreations

Email

Explain Everything

Google Drive

Google Maps

Google Translate

Haiku Deck

iBooks

ITunesU

Logger Pro

County Library

Notability

Pandora

Quizlet

Schoology

Show Me

Slideshark

Socrative

Synergy

WebBroser

Youtube

How did you use the iPad?

Created multimedia presentation

Did research

Took photos

Recorded audio or video

Worked on a writing project

Read

Solved math or science problems

Watched videos

Collaborated on a project with others

_Communicated via email

Listened to music

Played games

- Took notes

Used reference tools (e.g., dictionary, thesaurus)

Other: 


\section{Appendix 3. Teacher focus group protocol}

The purpose of our discussion is to share your experiences using the iPads with your students and your judgment of the impact of the technology on your students' engagement and learning.

Focus Group Questions April, 2013; April 2014

1. In general, what have been the strengths of the iPad project so far?

2. What have been the limitations or frustrations of the iPad project so far?

3. What are some ways your students have used the iPads that seemed to engage them the most?

4. What are some ways your students have used the iPads that seemed to have a positive impact on their learning?

5. To what extent has student use of the iPads noticeably affected student behavior in class?

6. To what extent has student use of the iPads noticeably affected student attendance in class?

7. To what extent has the 1:1 iPad project helped to reduce disparities in access to technology for your students?

8. To what extent has student use of the iPads affected the opportunity to individualize or differentiate instruction for your students?

9. If there is one thing this high school could do differently with the iPad project, what would it be?

\section{Corresponding author}

Gayle Y. Thieman can be contacted at: thiemag@pdx.edu 